Special Section : Man-Nature Relationship

Research Paper

\title{
Filling in the Gaps for Aquatic Ecosystem Conservation - Biomonitoring for Baseline Information and Capacity Building in Meghalaya, India
}

\author{
Sonali Saha $a^{1, *}$ Lucy Mary Jyrwa ${ }^{2}$, Marvellous B. Lynser ${ }^{2}$, Darina Kharchandi'2, Banri Dohling2, \\ Shanwell Khongwir ${ }^{2}$, Bashida Massar ${ }^{3}$ Amartya Saha ${ }^{4}{ }^{5}$ Pynbitbha Rynjah ${ }^{2}$, Banridor \\ Kharbyngar ${ }^{2}-$ Bakorshisha Kharjana ${ }^{2}$, Jane Kharbuddon ${ }^{5}$ Ibamaian Pariong $^{6}$, Sebastian \\ Syngkli ${ }^{5}$, Reuben Shabong ${ }^{7}$, Apbor R. Kharkongor ${ }^{8}$
}

\begin{abstract}
${ }^{1}$ Sonali Saha is an instructor of Biology at Miami Dade College and is engaged in building capacity in the field of freshwater ecosystem conservation and research in India. Miami Dade College, Miami-Dade College North Campus, 11380 NW 27 Avenue, Science Complex A322, Miami, Fl 33167, *Corresponding author: sahairc@gmail.com, +13057882873

${ }^{2}$ Lucy Mary Jyrwa is a professor of Zoology and spearheaded the year-long sampling in Lwai and Umkaliar rivers of Meghalaya. Dept of Zoology, Shillong College, Meghalaya, Laitumkhrah, Shillong, Meghalaya 793003, phone +919863023362, email : lmjyrwas@gmail.com

${ }^{2}$ Marvellous B. Lynser, is a professor of Environmental Science and spearheaded the year-long sampling in Lwai and Umkaliar rivers of Meghalaya. Dept of Environmental Science, Shillong College, Meghalaya, Laitumkhrah, Shillong, Meghalaya 793003, phone +91(364)-2224903, +919863570406 email : mlynser@gmail.com

${ }^{2}$ Darina Kharchandy, Dept. of Botany, Shillong College, Meghalaya, Laitumkhrah, Shillong, Meghalaya 793003,Dept of Botany, +919863061814, dkharshandi@yahoo.com

${ }^{2}$ Banrilang Dohling, Shillong College, Meghalaya, Laitumkhrah, Shillong, Meghalaya 793003, phone +91(364)2224903, banrishillong@gmail.com

${ }^{2}$ Shanwell Khongwir, Dept. of Zoology, Shillong College, Meghalaya, Laitumkhrah, Shillong, Meghalaya 793003, +919436341026, shanwell.k@yahoo.co.in

${ }^{3}$ Sebastian Syngkli, Dept. of Zoology, Northeastern Hill University, Umshing Mawkynroh, Shillong, Meghalaya 793022, India Meghalaya, sebastiansyngkli@gmail.com

${ }^{4}$ Bashida Massar, Dept. of Zoology, St. Anthony's College, Shillong, Bomfyle Road, Lachumiere, Shillong, Meghalaya 793001, mbashida74@gmail.com

${ }^{5}$ Amartya Saha, MacArthur Agro-ecology Research Center, 300 Buck Island Ranch Road, Lake Placid, Florida, 33852, USA, riparianbuffer@gmail.com

${ }^{2}$ Pynbitbha Rynjah², Shillong College, Meghalaya, Laitumkhrah, Shillong, Meghalaya 793003

${ }^{2}$ Banridor Kharbyngar², Shillong College, Meghalaya, Laitumkhrah, Shillong, Meghalaya 793003,

${ }^{2}$ Bakorshisha Kharjana ${ }^{2}$ Shillong College, Meghalaya, Laitumkhrah, Shillong, Meghalaya 793003, bakorshisha@reddiffmail.com

${ }^{3}$ Jane Kharbuddon, Dept. of Zoology, Northeastern Hill University, Umshing Mawkynroh, Shillong, Meghalaya 793022, India, janekharbudon@gmail.com

${ }^{6}$ Ibamaian Pariong, Dept of Zoology, Northeastern Hill University, NH 51, Chasingre, Tura, Meghalaya 794001, India

${ }^{7}$ Reuben Shabong, Indian Council for Agricultural Research, North Eastern Hill Region, Shillong, Meghalaya, Umiam, Meghalaya 793103, India, rwahlang@gmail.com

${ }^{8}$ Apbor R. kharkongor, Rngijynriew, Lawjynriew, Upper Nongthymmai, Shillong, Meghalaya, India, apbzrogie77@gmail.com
\end{abstract}




\begin{abstract}
This paper describes a stream biomonitoring program that builds capacity in undergraduate college students in the field of freshwater ecology and conservation. The program involves sampling of aquatic macroinvertebrates and hydrological parameters in streams of the state of Meghalaya, India. Several colleges from Shillong initiated short-term, one-year and long-term biomonitoring of streams in East Khasi Hills and Ri-Bhoi districts. Nine stream locations sampled over October-December in 2014 provided a snapshot of physical and biotic conditions, thus enabling the examination of spatial trends in water quality parameters and aquatic biota. A year-long sampling study from 2014-2015 provided a seasonal view of stream parameters at Lwai (clean) and Umkaliar (moderately polluted) streams. Results from both sampling sets suggest that turbidity negatively affected the richness of pollution sensitive taxa. Dissolved Oxygen values were lower in polluted streams and were non-significantly lower in summer than in winter. After an initial training in the field, the sampling was conducted by college students under supervision from their lecturers. Data obtained on macroinvertebrates adds to the sparse information available on stream ecosystems in the biodiversity-rich northeast Indian region. We hope the paper provides a template for monitoring of vital ecosystems in this and similar regions.
\end{abstract}

\section{Acknowledgements}

The inception of this study was made possible with grants from Rufford Foundation, UK to Sonali Saha in 2014 and 2016. Amartya Saha was supported by the USAID-funded Global Water for Sustainability Program, Florida International University. A FulbrightNehru Professional Excellence Award to Sonali Saha in 2015-2016 facilitated the strengthening of biomonitoring network. We also thank the Principal and faculty of Shillong College, Shillong, Meghalaya for funding a workshop on capacity building in conservation of freshwater ecosystems in 2014 and the staff of St. Anthony's College for hosting Sonali Saha as a visiting faculty member in 2015.

\section{Introduction}

Northeastern India is a region blessed with plentiful rainfall, streams and rivers, and is also part of the Eastern Himalayan biodiversity hotspot (Allen et al 2010). However, changing land use, growing water demands and pollution are rapidly altering water quality and quantity, and in the process destroying the diversity of life in the streams, rivers, lakes and wetlands in the Indian Northeast and tropical Asia in general (Dudgeon 2011, Massar and Saha 2016). There is very little information on freshwater aquatic ecosystem communities in the Northeast, or how these ecosystems are linked/maintained with water flow, quality, stream bank vegetation and watershed land use. Furthermore, there is very little public awareness of precisely how healthy aquatic ecosystems help maintain water quality in streams. As an initial means of addressing the lack of information, biomonitoring programs were developed in 2014 in several colleges in Shillong, Meghalaya in order to survey and monitor aquatic fauna, specifically macroinvertebrates of Meghalayan streams along with hydrological data. The programs were also conceived as a way to develop capacity of college students in the field of freshwater ecology and conservation. This article presents biomonitoring data from sampling conducted by undergraduate students and their supervising faculty from colleges of Shillong.

The role of aquatic macroinvertebrates in maintaining ecosystems

Aquatic macroinvertebrate assemblages comprise primarily of insect larvae that have terrestrial adult life forms, insects whose adult life-history stages such as beetles and true bugs are also aquatic, and include arthropods such as crustaceans, and organisms from other phyla such as mollusks (gastropods, bivalves), and annelids (Oligochaete, Hirudinea; Allan 1995, Meritt et al. 2008). Benthic macroinvertebrates are an important part of the food chain, especially for fish and other predators. Macroinvertebrates occupy different trophic levels in a food chain due to diverse feeding habits; many feed on algae and bacteria, some eat leaves and other organic matter, some are filterfeeders and quite a few are predatory on other insect larvae, crustaceans and small fish. Because of their abundance and intermediate position in the aquatic food chain, benthic macroinvertebrates play a critical role in the natural flow of energy and nutrients (Resh et al. 1995), including assisting in breakdown of leaf litter and organic matter decomposition. 


\section{Macroinvertebrates: links with water quality}

Macroinvertebrate assemblages show a strong correlation with variables of water quality and stream geomorphology (Resh et al. 1995, Lamouroux et al. 2004). In particular, the larvae of mayflies (Ephemeroptera), stoneflies (Plecoptera) and caddisflies (Tricoptera), or EPT taxa as they are collectively known, are globally associated with clear swift-flowing streams where they shelter underneath stones on the streambed, the sedimentation of which can thereby remove their habitat. Clear headwater streams are typically cool and highly oxygenated, especially in riffle sections. The EPT taxa larvae are more susceptible to the physical or chemical changes associated with pollution and siltation in a stream than other organisms. Thus, the presence of EPT insect larvae indicates the maintenance of the natural flow and water quality regimes, that in turn indicates a healthy catchment with regulated hydrology and lack of significant soil erosion and other forms of anthropogenic pollution. Pollution sensitive organisms act as indicators of the absence of pollutants. Pollution-tolerant organisms such as midges and worms are less susceptible to changes in physical and chemical parameters in a stream and their presence is an indirect measure of pollution. When a stream becomes polluted, pollution-sensitive organisms decrease in number or disappear; pollution-tolerant organisms increase in variety and number. Thus the maintenance of macroinvertebrate biodiversity is a critical test of whether the water use regime is sustainable (Dudgeon et al. 2004).

\section{Biomonitoring of aquatic ecosystems - a holistic} assessment of watershed ecosystem condition

Biological measures provide an integrative measure of stream health over space and time, as opposed to snapshots of stream conditions as obtained by physicochemical parameters (Karr 1999). The lack of effective soil conservation in farming, mining and roadbuilding all accelerate soil erosion with sediment being washed off into streams and rivers. The resulting siltation of streambeds covers rocks and thereby removes habitat for the aquatic larvae sheltering underneath rocks from the swift flowing currents (Feio et al. 2015). Alterations in the streamflow regime can also affect both the breeding and dispersal of invertebrates, as well as alter water quality, in particular, lower dissolved oxygen below the levels that swiftflowing stream fauna are used to (Williams 1996, Mesa 2012).
Biomonitoring of freshwater ecosystems using aquatic macroinvertebrate abundance and diversity is thus a widely used tool to assess the health of aquatic ecosystems and to determine policy intervention with regards to developing and enforcing regulation for water quality (Bonada et al. 2006, Kennedy et al. 2009). Biological stream monitoring is based on the fact that different species react to pollution in different ways. Biomonitoring also adds the possibility of encountering new species that are not known to science and can enhance the understanding of life history traits of macroinvertebrates. As a consequence of all these benefits, biomonitoring is being mainstreamed into policy regulations for managing water quality in streams and rivers.

\section{Biomonitoring as a tool for building capacity in society}

Documentation of stream and river conditions using aquatic macroinvertebrates is an appropriate tool to develop capacity in the field of freshwater ecosystem science and conservation (Goulden 2009), especially in region rich in springs, streams, and aquatic biodiversity such as Meghalaya. However, it has never been put in practice before in this region. This pioneering hands-on experience brings students in close contact with the ecosystem. Periodic monitoring develops an appreciation for the links between a diverse ecosystem and the physico-chemical parameters of water quality and flow that maintain life. Biomonitoring of streams and rivers enables students to relate river parameters such as water depth and discharge to the daily availability of water as well as with extreme events such as floods and droughts. By correlating the diversity and abundance of freshwater taxa with water quality and quantity, baseline ecohydrology information on streams and rivers can be obtained; rivers harboring healthy and diverse ecosystems would be considered reference sites as benchmark for restoration. Thus biomonitoring enhances the understanding of rivers as living parts of the landscape, which needs ecologically-guided maintenance and protection, and not just as a natural resource to be harvested. In this article we summarize results from biomonitoring projects that have been undertaken since 2014 by different colleges in Meghalaya.

\section{Study Site and Methods}

\section{Creating a capacity building network}

This study was conducted by the members of a biomonitoring network which was established in 2014 
as a part of capacity building program in Meghalaya to develop baseline data on hydrological parameters and macroinvertebrate diversity in streams and rivers with the help of undergraduate college students and their advisors. In a 10-day workshop held in July 2014, students were introduced to the tools of scientific method and research in the field of freshwater ecology and conservation. Field trips were organized where students learned the methods of biomonitoring and measuring water quality and hydrological parameters with the experts in the field. We had a total of 70 students participating with eighteen faculty members. The entire group was divided into subgroups supervised by 1 or 2 faculty members. Each subgroup learned and independently conducted measurements of different parameters. A total of six colleges from Shillong were part of the network, with each college with the team of 10-15 students and two faculty members. Each participating college chose a stream to monitor based on convenience of access and selected a sampling regime that was contingent on funds and time at the team's disposal. Table 1 lists the streams, sampling regime, site location, and parameters measured while Figure 1 shows the locations in Meghalaya where stream biomonitoring was conducted by students representing six colleges of Shillong.

Meghalaya is a state in Northeast India with annual rainfall averaging to $1150 \mathrm{~cm}$; it is an extremely wet place, with the world's highest rainfall occurring at Cherrapunjee-Mawsynram (Basumatary et al. 2013), but with increasing water shortages in the dry season. Topographically Meghalaya is a plateau peaking at the altitude of $1964 \mathrm{~m}$. The catchment divide is oriented in an east-west direction bisecting the state so that the north facing slopes drain into the Brahmaputra river, while the sharply incised southern slopes rapidly drain into Bangladesh to join the BarakMeghna river system. Sites were chosen on both northern and southern sides of the topographic divide in Meghalaya (Table 1, Figure 1) across a variety of land use patterns in the catchment resulting in varying degrees of habitat impairment and pollution. Both temporally intensive (year-long study) and spatially extensive (spot sampling) regimes of sampling were conducted.

The temporally intensive study consisted of a yearlong monthly sampling of two streams - Umkaliar (in Shillong, polluted) and Lwai (22 km from Shillong, unpolluted). This study was conducted by Shillong College from October 2014 to September 2015. Umkaliar, stream drains the Shillong urban area and thus is subject to pollution from domestic and municipal greywater discharge, solid waste, construction site debris, car washing, small industrial pollution and stormwater runoff carrying oils and grease from roads. Lwai on the other hand is much less polluted, as the catchment is largely a mix of terraced agriculture and forests, although increasing farming has the potential for sedimentation and agrochemicals.

The spatially extensive study consisted of a onetime or bi-annual spot sampling of Lawjynriew, Malki, Mawshubuitin, Umshyrpi and Wahdienglieng streams located in and around Shillong urban area $\left(25^{\circ} 32^{\prime} 10^{\prime \prime} \mathrm{N}\right.$ to $25^{\circ} 36^{\prime} 20^{\prime \prime} \mathrm{N}$ latitude and $91^{\circ} 51^{\prime} 30^{\prime \prime}$ to $91^{\circ} 51^{\prime} 30^{\prime \prime}$ E longitude) during the monsoonal rains (May to September in Meghalaya) and in the winter (December-February). In addition, two sites on the northern side of the divide were on streams of the Umran river draining the foothills in Ri Bhoi district near Umsning Village $\left(25^{\circ} 44^{\prime} 1.2^{\prime \prime} \mathrm{N}\right.$ latitude and 91 $51^{\prime} 35^{\prime \prime}$ E longitude) amidst mixed agriculture and forest. Three sites were on the southern flanks of the topographic divide near Lapalang village on the Rymben river in East Khasi Hills District, about $60 \mathrm{~km}$ southeast of Shillong. The Rymben is a fast flowing river with pools and riffles draining the southern flanks of the East Khasi Hills very close to the border with Bangladesh. The catchment is dominated by mixed agriculture in valley bottoms, cultivation of broomgrass and betelnut, with native evergreen forests remaining on steep slopes. Spot sampling was conducted by colleges that had limited resources and time to dedicate for fieldwork. Spot sampling enabled observing the spatial variation in water quality, hydrology, and biotic index, even though this was done once or twice. Multiple sections separated by at least 2 $\mathrm{km}$ and belonging to different stream orders of Umshyrpi and Umran river network were sampled. Table 2 lists the dominant riparian vegetation present along each of the stream courses (although it was beyond the scope of the study to assess percent cover of riparian vegetation).

\section{Biomonitoring using benthic macroinvertebrates}

Macroinvertebrates were collected from shallow riffle habitats in streams that students could access. Three stream reaches $50 \mathrm{~m}$ apart were chosen for sampling per stream site. Macroinvertebrates were collected by flushing organisms from under the rocks, floor of the channel and debris and were collected in a net held just below or downstream of the sample area. Wood, stones and debris collected from the net was sorted for macroinvertebrates and the samples pre- 
Table 1 : Stream biomonitoring conducted by students from different colleges in Meghalaya.

*For these streams two distinct lower order streams from their catchment network were chosen for sampling.

DO (Dissolved Oxygen).

\begin{tabular}{|c|c|c|c|c|c|}
\hline Stream/river & Location & $\begin{array}{l}\text { Sampling } \\
\text { regime }\end{array}$ & $\begin{array}{l}\text { Sampling } \\
\text { performed }\end{array}$ & $\begin{array}{l}\text { Parameters } \\
\text { sampled }\end{array}$ & $\begin{array}{l}\text { Hydrological } \\
\text { variables }\end{array}$ \\
\hline Lwai & $25^{\circ} 27^{\prime} 59.1^{\prime \prime} \mathrm{N} 91^{\circ} 56^{\prime} 04.5^{\prime \prime} \mathrm{E}$ & Monthly & Sep 2014-2015 & $\begin{array}{l}\text { Macroinvertebrates } \\
\text { DO, turbidity, } \\
\text { nitrates, TDS }\end{array}$ & None \\
\hline Lawjynriew & 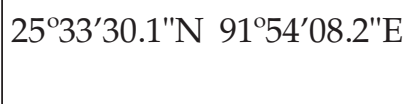 & One-time & Oct 2014 & $\begin{array}{l}\text { Macroinvertebrates } \\
\text { DO, turbidity }\end{array}$ & Discharge \\
\hline Malki & $25^{\circ} 33^{\prime} 21.3^{\prime \prime} \mathrm{N} 91^{\circ} 53^{\prime} 27.4^{\prime \prime} \mathrm{E}$ & One-time & Oct 2014 & $\begin{array}{l}\text { Macroinvertebrates } \\
\text { DO, turbidity }\end{array}$ & Discharge \\
\hline Mawshubuit & 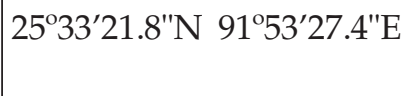 & One-time & Oct 2014 & $\begin{array}{l}\text { Macroinvertebrates } \\
\text { DO, turbidity }\end{array}$ & Discharge \\
\hline Rymben & $25^{\circ} 11^{\prime} 34.8^{\prime \prime} \mathrm{N} 91^{\circ} 57^{\prime} 29^{\prime \prime} \mathrm{E}$ & One-time & Nov 2015 & $\begin{array}{l}\text { Macroinvertebrates, } \\
\text { DO, turbidity }\end{array}$ & Discharge \\
\hline $\begin{array}{l}\text { Umran* } \\
\left(2^{\text {nd }} \text { and } 4^{\text {th }}\right. \\
\text { order streams })\end{array}$ & $25^{\circ} 33^{\prime} 21.8^{\prime \prime} \mathrm{N} 91^{\circ} 53^{\prime} 27^{\prime \prime} \mathrm{E}$ & One-time & August 2014 & $\begin{array}{l}\text { Macroinvertebrates } \\
\text { DO, turbidity }\end{array}$ & Discharge \\
\hline Umkaliar & $25^{\circ} 34^{\prime} 44.4^{\prime \prime} \mathrm{N} 91^{\circ} 54^{\prime} 24.4^{\prime \prime} \mathrm{E}$ & Monthly & Sep 2014-2015 & $\begin{array}{l}\text { Macroinvertebrates } \\
\text { DO, turbidity, } \\
\text { nitrates, TDS }\end{array}$ & None \\
\hline $\begin{array}{l}\text { Umshyrpi*, } \\
1^{\text {st }} \text { order } \\
3^{\text {rd }} \text { order } \\
\text { streams }\end{array}$ & $\begin{array}{l}25^{\circ} 33^{\prime} 11.9^{\prime \prime} \mathrm{N} 91^{\circ} 52^{\prime} 09.8^{\prime \prime} \mathrm{E} \\
25^{\circ} 33^{\prime} 07.9^{\prime \prime} \mathrm{N} 91^{\circ} 51^{\prime} 42.6^{\prime \prime} \mathrm{E}\end{array}$ & Bi-yearly & Oct-Dec 2014 & $\begin{array}{l}\text { Macroinvertebrates, } \\
\text { DO, turbidity, } \mathrm{pH}\end{array}$ & Discharge \\
\hline Wahdienglieng & 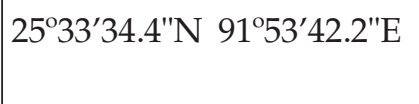 & One-time & $\begin{array}{l}\text { Oct } 2014 \\
\text { Jan } 2015\end{array}$ & $\begin{array}{l}\text { Macroinvertebrates } \\
\text { DO, turbidity, } \mathrm{pH}\end{array}$ & None \\
\hline
\end{tabular}

served (in 70\% ethyl alcohol). Pools are the other main type of physical stream habitat but do not contain the abundance and diversity of macroinvertebrate fauna found in riffles (however, being deeper and having calmer water, pools constitute the preferred habitat for the larger stream fish such as trout and mahseer). This collection contains aquatic invertebrates in proportion to their relative abundance within the riffle sample areas. Samples were identified up to the order level and in some cases up to the family level.

To assess the stream conditions, a scoring process was used to derive metric value that relies on macroinvertebrate abundance and diversity data (Sharpe et al. 2002). Grossly polluted streams have scores ranging from $0-2$, moderately polluted streams range from 3-9, and clean streams have value of 10 . The index value is obtained by allocating a higher score to the species richness of pollution sensitive taxa belonging to the insect orders Ephemeroptera (mayflies), Plecoptera (stoneflies) and Trichoptera (caddisflies, excluding the net spinning caddisfly), a lower score to richness of taxa belonging to insect 
Table 2. Description of riparian vegetation bordering the sampled streams.

\begin{tabular}{|c|c|}
\hline Stream & Vegetation \\
\hline Lwai & $\begin{array}{l}\text { Riparian vegetation included understorey tree of Litsea spp., and shrubs belonging to genera } \\
\text { Ardisia, Psychotria, Pittosporum, and tree fern Cyathea gigantea }\end{array}$ \\
\hline Lawjynriew & $\begin{array}{l}\text { Riparian zone was dominated by shrubs-Mahonia pycnophylla, Daphne papyraceae, Polygala } \\
\text { arillata, Camellia caduca, Rubus spp., and herbs belonging to families Balsaminaceae and } \\
\text { Asteraceae }\end{array}$ \\
\hline Malki & $\begin{array}{l}\text { Riparian plants were shrubs- Mahonia pycnophylla, Daphne papyraceae, Polygala arillata, } \\
\text { Camellia caduca, Rubus spp., and herbs belonging to families Balsaminaceae and Asteraceae }\end{array}$ \\
\hline Mawshubuit & $\begin{array}{l}\text { Mahonia pycnophylla, Daphne papyraceae, Polygala arillata, Camellia caduca, Rubus spp., and } \\
\text { herbs belonging to families Balsaminaceae and Asteraceae }\end{array}$ \\
\hline Rymben & $\begin{array}{l}\text { The riparian vegetation consists of steep slopes lining the perennial river which has } \\
\text { mid-sized trees of Syzygium spp., Tetrameles nudiflora and shrubs such as Dracaena elliptica, } \\
\text { Leea edgeworthia, while plantations of Areca catechu mixed with species of Artocarpus, } \\
\text { Cinnamomum and Bauhinia occur on gentle slopes. }\end{array}$ \\
\hline $\begin{array}{l}\text { Umran* } \\
\text { (2nd and } 4 \text { th } \\
\text { order streams) }\end{array}$ & $\begin{array}{l}\text { In the first order stream the riparian vegetation consisted of Ardisia spp., Dracaena elliptica, } \\
\text { Leea edgeworthia, Phlogacanthus sp., and other species belonging to the family Acanthaceae, } \\
\text { Rubiaceae, Balsaminaceae and Asteraceae. The third order stream dominated by dense grassy } \\
\text { vegetation including broom grass Thysanolaena maxima and woody taxa such as Syzygium } \\
\text { and Leea. }\end{array}$ \\
\hline Umkaliar & $\begin{array}{l}\text { Trees belonging to Litsea spp., and shrubs belonging to genera Ardisia, Psychotria, Pittosporum, } \\
\text { and tree fern Cyatheae }\end{array}$ \\
\hline $\begin{array}{l}\text { Umshyrpi*, } \\
\text { 1st order and } \\
\text { 3rd order } \\
\text { streams }\end{array}$ & $\begin{array}{l}\text { 1st order stream had the shrubs Lasianthus hookerii, Ardisia sp. and herbs such as Costus sp. } \\
\text { The bank of 3rd order stream was impacted by human activities. It had trees of Syzygium sp., } \\
\text { and Melocanna bamboo clumps and other grass taxa. }\end{array}$ \\
\hline Wahdienglieng & Trees of Syzygium sp., Litsea sp. Ficus sp., grass taxa and human settlements \\
\hline
\end{tabular}

orders Odonata, Megaloptera, some Coleopterans, and crustacean orders, Isoptera and Amphipoda, while the pollution tolerant taxa are not scored at all. Pollution tolerant taxa are Dipteran (true flies) larvae, adult aquatic Coleopterans (beetles), Mollusca order Gastropoda (snails) and aquatic earthworms, Oligochaeta, Hemipterans and surface film insects.

Biotic Index was calculated as

Biotic Index $=2(\mathrm{n}$ Class $\mathrm{I})+(\mathrm{n}$ Class II $)$

where $\mathrm{n}=$ number of taxa (species richness per category of taxa)

Pollution sensitive taxa belong to Class I while moderately sensitive taxa belong to Class II. Pollution tolerant taxa belonging to Class III are not considered in the calculation of Biotic Index. Samples were identified using a pictorial field guide (Subramaniam and Sivaramakrishnan 2007) to key taxa up to the family level when possible.

\section{Hydrological, physical and chemical parameters}

Concurrent measurement of river discharge, dissolved oxygen, $\mathrm{pH}$, temperature and turbidity were made. To measure stream discharge, stream velocity was obtained using the classic float method (tennis 


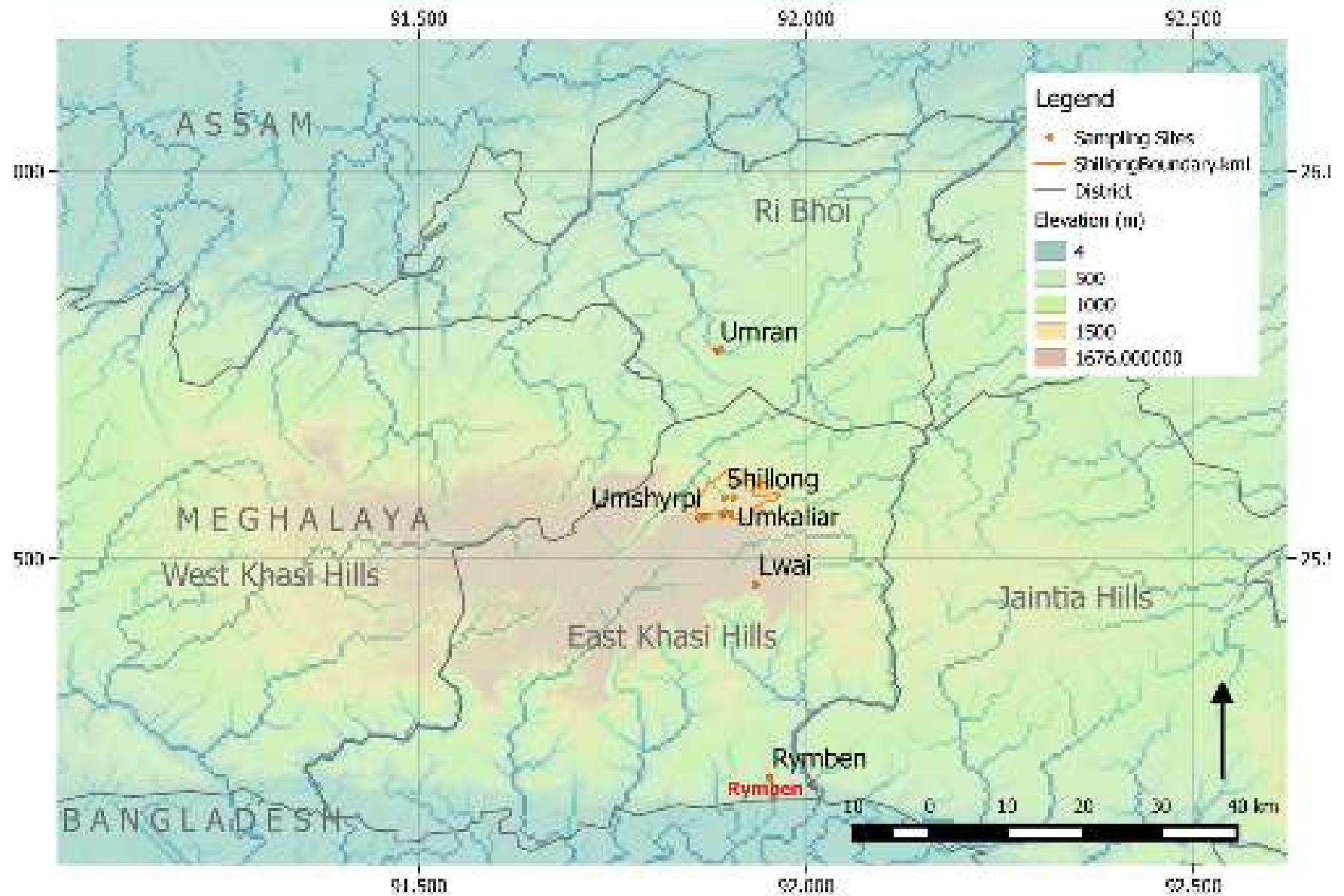

Figure 1: Study site groups (Umran, Shillong and Rymben) represented by orange dots in Ri Bhoi and East Khasi Hills Districts in Meghalaya. Shillong urban boundary is delineated by the orange line. Map generated by drainage network delineation using QGIS upon ASTER 30 m Digital Elevation Model. Umkaliar is within Shillong city while Lwai stream is further away from the city or any other larger towns
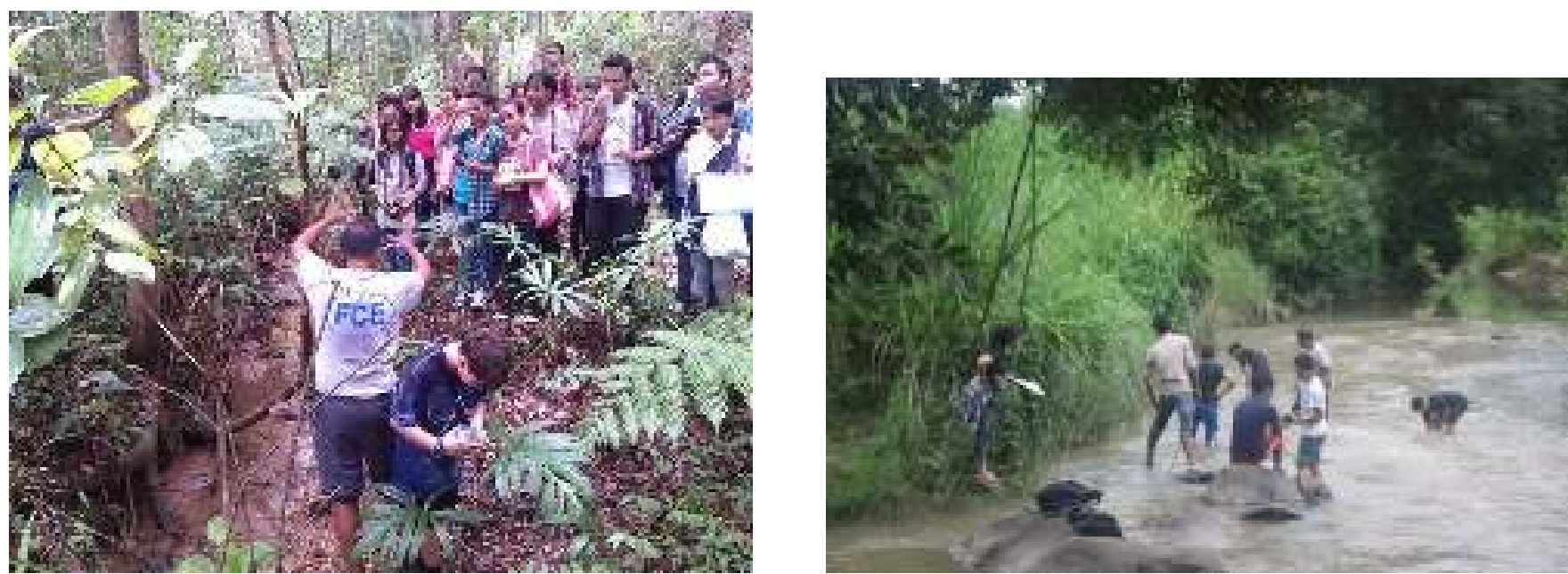

Figure 2: Students measuring discharge and collecting macroinvertebrates in the 2 nd and 4 th order streams of Umran river near Umsning village, Ri Bhoi District, Meghalaya. 
ball) or mechanical current meter (General Oceanics 2030R, Miami, USA) and multiplied by stream cross sectional area (average channel depth*channel width). Dissolved oxygen (DO) was measured using a hand held portable dissolved oxygen meter (Milwaukee MW600, Milwaukee Instruments, North Carolina, USA).

Turbidity measurements were made with a turbidity tube (Meyer and Shawn 2006). The turbidity tube uses the correlation between visibility and turbidity to approximate a turbidity level. A marker is placed at the bottom of the turbidity tube until it can no longer be seen from above due to the murkiness of the water. This height from which the marker can no longer be seen correlates to a known turbidity value which is reported in Nephelometric Turbidity Units (NTU). Cloudier the water, higher is the turbidity value.

\section{Results}

Biomonitoring Network: A capacity building initiative

The biomonitoring network consisting of institutions from Shillong conducted stream surveys and monitoring of hydrological and water quality parameters. The colleges that participated in the network and sampled selected streams (stream names in parentheses) were: Lady Keane College (Umran), Shillong College (Lwai, Umkaliar, Umran streams), Sankardev College (Umshyrpi river), St. Anthony's College (Wahdienglieng), St. Mary's College (Umran), Synod College (Umran), and Umshyrpi College (Umshyrpi). Besides academic institutions three independent researchers from Shillong with Master's degree in Ecology also participated and shared their data (Lawjynriew, Malki, Mawshubuit). Equipment were provided to the network participants and in some cases the colleges purchased the equipment for sampling. This is the first time such a data set is being presented and analyzed to understand emerging trends in the region.

Year-long study: Trends from Umkaliar and Lwai streams

\section{Water Quality}

Data taken monthly from Umkaliar and Lwai

Table 3 : Summary table showing mean values of the measured water quality and hydrology parameters collected from year-long and spot sampling.

\begin{tabular}{|l|l|l|l|l|}
\hline Stream/river & $\begin{array}{l}\text { Mean DO } \\
\text { mg L-1 }\end{array}$ & $\begin{array}{l}\text { Mean Turbidity } \\
\text { NTU }\end{array}$ & $\begin{array}{l}\text { Mean Biotic } \\
\text { Index }\end{array}$ & $\begin{array}{l}\text { Mean Discharge } \\
\mathbf{m}^{3} / \mathbf{s}\end{array}$ \\
\hline Lwai & 7.5 & 15.5 & 14.6 & Not collected \\
\hline Lawjynriew & 7.3 & 5 & 18 & 0.001 \\
\hline Malki & 8.6 & 45 & 10 & 0.025 \\
\hline Mawshubuit & 12.5 & 4 & 18 & 0.008 \\
\hline Rymben & 8.7 & 4 & 12 & 2.53 \\
\hline $\begin{array}{l}\text { Umran* (2nd and } \\
\text { 4th order streams) }\end{array}$ & 12.2 & 4 & 16 & 0.030 \\
\hline Umkaliar & 5.7 & 7 & 8 & 2.83 \\
\hline $\begin{array}{l}\text { Umshyrpi* } \\
\text { 1st order }\end{array}$ & 12 & 22.6 & 14.5 & Not collected \\
\hline 3rd order streams & 6.8 & 15 & 12 & 0.025 \\
\hline Wahdienglieng & 8.4 & 40 & 8.62 \\
\hline
\end{tabular}



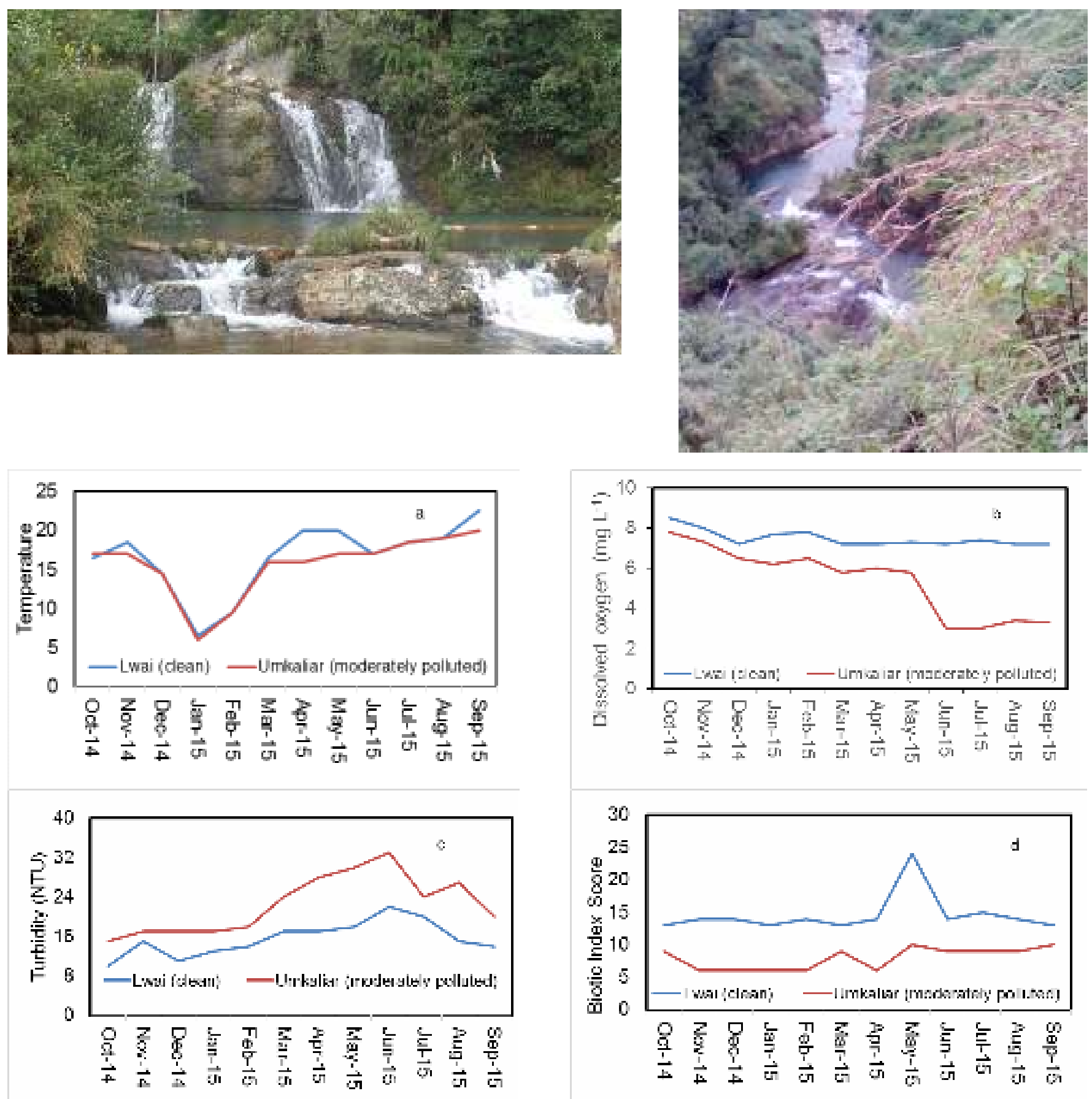

Figure 3 : Pictures of Umkaliar and Lwai streams followed by data graphs.

$a$ : Temperature variation across months, Lwai stream was marginally warmer than Umkaliar stream. $b$ : Trend in dissolved oxygen at Lwai and Umkaliar streams over a sampling period of one year, DO at Lwai was significantly higher than Umkaliar. The trend in relation to temperature is sharper for the polluted stream compared to clean Lwai stream.

$c$ : Turbidity was significantly higher in Umkaliar than Lwai stream. $d$ : Biotic index scores based on sampling of macroinvertebrates from the riffle sections of the streams. Biotic index values obtained at Lwai, indicate that the stream is fairly clean. 

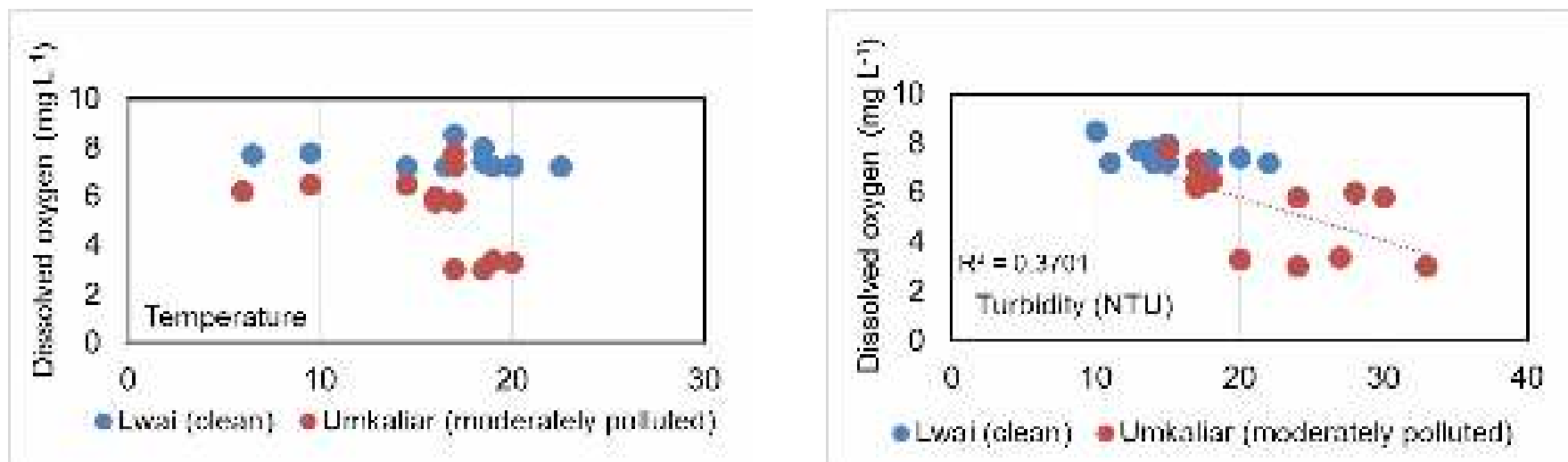

Figure 4: Left panel shows a non-significant decline in DO in relation to stream temperature in moderately polluted stream, while in Lwai stream DO stayed stable across the year. Right panel also depicts that turbidity explains a significant trend in DO values in moderately polluted stream, while in Lwai stream the pattern is non-significant.

streams showed seasonal trends in temperature and dissolved oxygen (DO). DO values increased with decrease in water temperature accompanying the onset of winter. Seasonal difference in DO was greater in the polluted Umkaliar stream (average of $5.7 \pm 0.92$ mg L-1 Figure 3 upper panel) as compared to Lwai, because summer DO values in the Umkaliar dropped much lower.

A set of paired $t$-tests were used to compare the differences in monthly $\mathrm{DO}$, temperature and turbidity between the two streams. Temperature in Lwai stream was marginally higher than Umkaliar stream across the entire year $(t=2.1, d f=11, P=0.05$, with mean of 16.8 $\mathrm{OC}$ at Lwai and 15.4 $\mathrm{OC}$ at Umkaliar; Figure 3a). The temperature difference could be due to the higher altitude and temperate climate of Umkaliar stream as compared to Lwai stream that is in sub-tropical habitat. Dissolved oxygen at each monthly sampling event was significantly higher in Lwai compared to Umkaliar stream $(\mathrm{t}=4.46, \mathrm{df}=11, \mathrm{P}<0.001$, with mean of $7.6 \mathrm{mg} \mathrm{L}-1$ at Lwai and $5.7 \mathrm{mg}$ L- at Umkaliar; Figure $3 b)$. Turbidity values were significantly higher in Umkaliar stream than Lwai strean $(\mathrm{t}=4.89, \mathrm{df}=11$, $\mathrm{P}<0.001$, with mean values of 22.6 NTU at Umkaliar and 15.5 NTU at Lwai and; Figure 3c). Turbidity did not show a specific seasonal pattern. Since biotic index is a derived variable we did not perform a paired $t$ test. Results of water quality parameters are summarized in Table 3 for both Lwai and Umkaliar streams.

Variations in dissolved oxygen and turbidity were not explained by temperature (Figure 4 upper panel). Turbidity however had a marginally significant effect on dissolved oxygen and explained variation in $\mathrm{DO}$ values $(P=0.05, R 2=0.37$; Figure 4 lower panel).

\section{Biotic index}

Lwai stream had a higher biotic index with an average of $14.6 \pm 0.8$ (mean \pm SE; Figure $3 \mathrm{~d}$ ) which is an indication of clean streams, as compared to Umkaliar stream where the average biotic index score was $8 \pm 1.4$ indicating a moderately polluted stream. Lwai harbored a higher diversity of pollution sensitive taxa - caddisflies, stoneflies, mayflies, adult water beetles, water scorpions and snails were commonly found (Table 2). On the other hand, leeches, mosquito larvae, midge larvae, snails, and mayflies were frequently encountered in the Umkaliar stream. No seasonal trends in biotic index were observed in Lwai or Umkaliar streams. The only high index value was observed for May 2015 at Lwai stream. No significant effect of seasonality were found on biotic index score for both the Lwai and Umkaliar streams.

\section{Spot sampling in 8 streams: spatial inferences}

The dataset from 8 streams sampled (Table 1) were pooled to examine if there was spatial variation in biotic index, turbidity, temperature and discharge in the region. Table 3 provides a summary of results from all streams included to represent spot sampling regime.

\section{Stream discharge:}

Seasonal discharge varied among sites as a factor of channel width and stream morphology. Most 1st and 2nd order streams showed lower and comparable discharge values while the larger 3rd and 4th order streams showed higher discharge values owing to larger channel widths. 

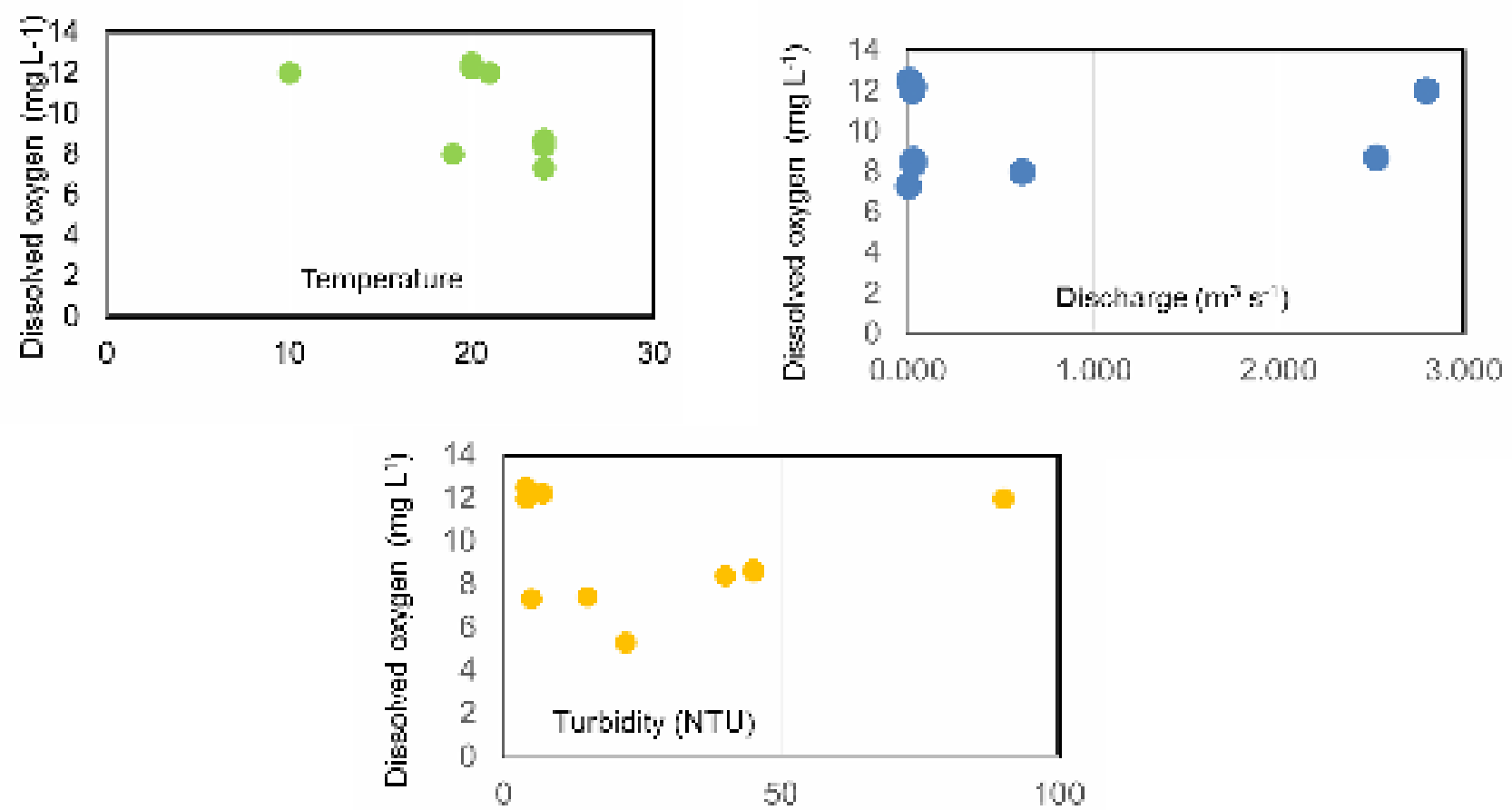

Figure 5: Spatial variation in relationship between DO and the variables- temperature, turbidity, and discharge. Upper left panel depicts a DO against temperature across the entire spectrum of streams sampled in Shillong; Upper right panel shows that discharge can be categorized as low values within 1st and 2nd order streams, intermediate value for 3rd order stream and highest for 4 th order stream. Lower panel depicts the values of DO across a range of turbidity among the sampled streams.

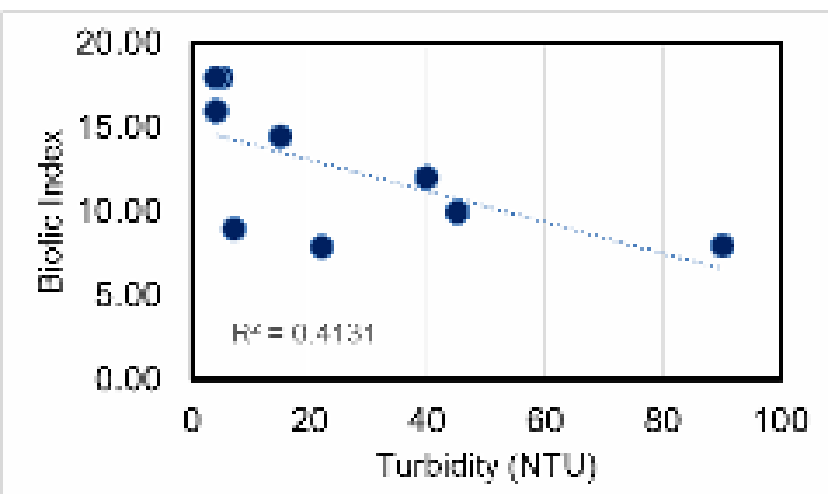

Figure 6: Plot of biotic index against turbidity in spot sampling of 8 streams in Meghalaya. Increase in turbidity resulted in a significant decline of biotic index which is an indicator of macroinvertebrate diversity and abundance among pollution sensitive taxa.

\section{Water quality}

Dissolved oxygen values showed a non-significant decline with increase in water temperature (Figure 5 upper panel). Cooler waters have greater capacity to hold dissolved oxygen as compared to warmer waters, but the results were not significant.
No significant relationship was observed between discharge and dissolved oxygen concentration (Figure 5 middle panel) possibly because these were all fastflowing streams that differed in discharge owing to channel width and not flow velocity. While higher DO values result from higher flow velocities on account of oxygenation of water from air entrapment, all streams 

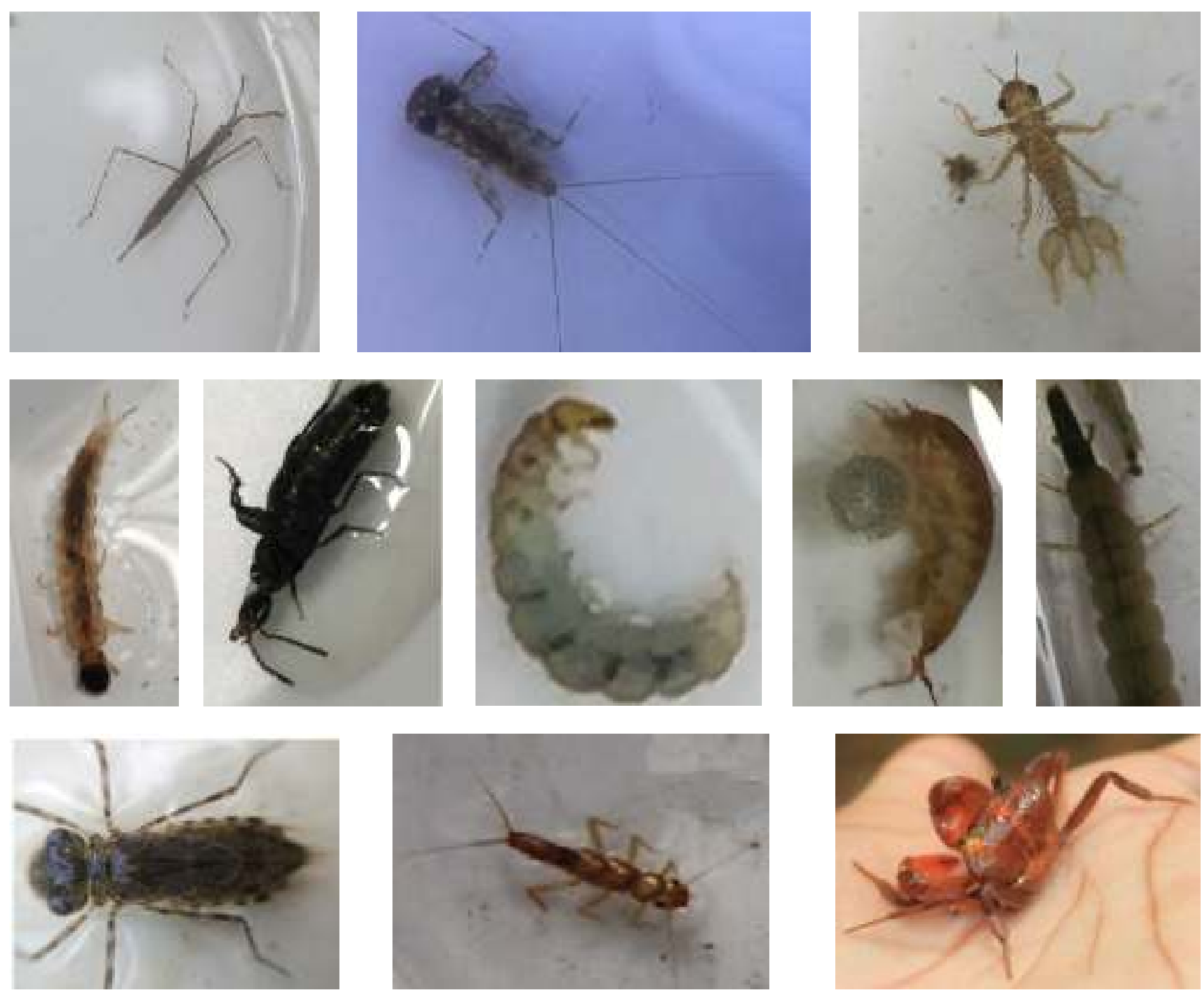

Figure 7 : Some specimens of macroinvertebrate larvae encountered in Meghalaya streams:

Top row, left to right: Water scorpion of Ranatra sp. (Family Nepidae, Order-Hemiptera), Mayfly larva of Family Heptageniidae, (Order- Ephemeroptera), damsel fly larva of Family Coenagrionidae (Order Odonata).

2nd row from top, left to right: Caddisfly larvae of Family Polycentropodidae (Order Trichoptera), Rove beetle of Family Staphylinidae (Order Coleoptera) -- not strictly aquatic but hunt along margins of water bodies), Caddisfly larva of Family Rhyacophilidae (Order Trichoptera), Amphipod (Order Amphipoda, Subphylum Crustacea), Caddisfly larva of Family Stenopsychidae, (Order Trichoptera),

3rd row from top, left to right: Dragonfly larva of Family Corduliidae (Order Odonata), Stonefly larva of Order Plecoptera and Crab (Crustacea) of Genus Liotelphusa, family Gecarcinucidae. 
Table 4: Common macroinvertebrates sampled from the riffle sections of streams in Meghalaya

\begin{tabular}{|l|l|l|l|}
\hline Stream/river & Location & $\begin{array}{l}\text { Sampling } \\
\text { regime }\end{array}$ & Macroinvertebrates \\
\hline Lwai & East Khasi Hills & $\begin{array}{l}\text { Monthly, } \\
\text { Sep 2014-2015 }\end{array}$ & $\begin{array}{l}\text { Caddisflies, stoneflies, mayflies, adult water } \\
\text { beetles, water scorpion, mosquito larvae, snails }\end{array}$ \\
\hline Lawjynriew & East Khasi Hills & $\begin{array}{l}\text { One-time, } \\
\text { Oct-2014 }\end{array}$ & $\begin{array}{l}\text { Caddisflies, stoneflies, mayflies, hellgrammite, } \\
\text { dragonfly, water scorpion, midge larvae }\end{array}$ \\
\hline Malki & East Khasi Hills & $\begin{array}{l}\text { One-time, } \\
\text { Oct-2014 }\end{array}$ & $\begin{array}{l}\text { Caddisflies, stoneflies, mayflies, dragonfly, adult } \\
\text { water beetles, water scorpion }\end{array}$ \\
\hline Mawshubuit & East Khasi Hills & $\begin{array}{l}\text { One-time, } \\
\text { Oct-2014 }\end{array}$ & $\begin{array}{l}\text { Caddisflies, stoneflies, mayflies, midge larvae, } \\
\text { mosquito larvae }\end{array}$ \\
\hline Umran 2nd order & Ri-Bhoi & $\begin{array}{l}\text { One-time, } \\
\text { July-14, Jan-14 }\end{array}$ & $\begin{array}{l}\text { Caddisflies, stoneflies, mayflies, dragonfly, adult } \\
\text { water beetles, water scorpion, crabs }\end{array}$ \\
\hline Umran 4th order & Ri-Bhoi & $\begin{array}{l}\text { One-time, } \\
\text { July-14, Jan-14 }\end{array}$ & $\begin{array}{l}\text { Caddisflies, mayflies, adult water beetles, aquati } \\
\text { earthworms }\end{array}$ \\
\hline Umkaliar & East Khasi Hills & $\begin{array}{l}\text { Monthly, } \\
\text { Sep 2014-2015 }\end{array}$ & $\begin{array}{l}\text { Leech, mosquito larvae, midge larvae, snails, } \\
\text { mayflies }\end{array}$ \\
\hline Umshyrpi 1st order & East Khasi Hills & Once Oct-14 & $\begin{array}{l}\text { Caddisflies, stoneflies, mayflies, amphipod, adult } \\
\text { water beetles, aquatic earthworms, snails }\end{array}$ \\
\hline Umshyrpi 3rd order & East Khasi Hills & Once Oct-14 & $\begin{array}{l}\text { Adult water beetles, blackfly and midge larvae, } \\
\text { aquatic worms, snails }\end{array}$ \\
\hline
\end{tabular}

had high flows with possibly maximum oxygenation. Biochemical Oxygen Demand (BOD) also affects DO; however measuring BOD of different streams was beyond the scope of the study.

Turbidity did not influence dissolved oxygen concentration (Figure 5 lower panel). Oxygenation of streams from turbulent flow can alleviate the negative impact of high turbidity on DO.

\section{Macroinvertebrates}

Biotic Index value across sites was negatively influenced by turbidity indicating that streams with lesser richness and lesser abundance of pollution sensitive taxa tend to have murky waters $(\mathrm{P}<0.001, \mathrm{r} 2=0.38$;
Figure 6). Neither the index values nor the turbidity were influenced by temperature, thus the seasonality did not have confounding effects on the underlying pattern. Clearwater streams were found to have a higher Biotic Index, as determined by the occurrence of pollution-sensitive EPT taxa (mayfly, stonefly and caddisfly larvae). Interestingly, our limited sampling shows that the Biotic Index values are not influenced by dissolved oxygen in Meghalayan hill streams. A likely reason is that majority of streams are fast running owing to the high rainfall and steep topographic gradients, which increases oxygenation and can potentially offset the high BOD resulting from dumping of organic waste especially within the streams flowing 
through Shillong. Figure 7 shows some of the invertebrates encountered in sampling. Table 4 summarizes the taxonomic groups (insect orders) observed at different stream locations. Studies in Meghalayan streams have reported 17 Ephemeropteran taxa across a diversity of stream habitats and land use (Gupta and Michael 1992). It is also known that macroinvertebrates are aseasonal in their activity. While several important ecosystem services are provided by streams and rivers, the ecology and life-history traits of Ephemeropterans and aquatic macroinvertebrates in the tropics in general are poorly studied (Gupta 1993, Dudgeon 1999, Hamid et al. 2016).

\section{Discussion}

The biomonitoring initiative in Meghalaya was set up with a dual aim:

1. to infuse curiosity, to introduce students to the scientific method of asking and answering questions in stream ecology, and to establish in their minds the links between healthy aquatic ecosystems, water availability and quality;

2. to begin the process of documenting macroinvertebrate diversity in conjunction with hydrological and physico-chemical parameters of streams, so that eventually a metric for streams in Meghalaya can be established, which could be used state-wide.

While stream biomonitoring with benthic macroinvertebrates is a tool for guiding policy on setting effluent limits and water quality standards (Kennedy et al. 2009), capacity building in freshwater ecology is a novel application of biomonitoring. Several colleges from Shillong, Meghalaya, participated in designing the studies, collecting and analyzing data, the results of which were presented in international conferences (Saha 2016) and college seminars. While several studies have looked at diversity and abundance of macroinvertebrates as a biomonitoring tool in Indian streams and rivers (for example, Martin et al. 2000, Shah and Shah 2013), few studies exist in the Indian Northeast. Figures 3-7 provide a glance at some results from our work.

\section{Comparing aquatic invertebrate assemblages in streams with contrasting water quality}

The summer water temperature values were almost four times higher than mid-day winter water temperature. Dissolved oxygen showed a non-significant decline in summer months especially in the polluted Umkaliar stream while showing stable values in Lwai stream. Cooler water temperatures support greater DO levels than warmer temperatures (Michaud 1991, Wetzel 2001). We observed some low DO values in Umkaliar stream during summer season, when DO values were around $3 \mathrm{mg} \mathrm{L-1.}$

Dissolved oxygen is the most important abiotic parameter that influences the health and composition of aquatic communities, macroinvertebrates and fish require a certain amount of dissolved oxygen to survive (Flint and Pearson 2015). Dissolved oxygen in the summer months, especially early summer after the rains set in is reported to be very low in Umkaliar because of flushing of raw sewage and organic waste from the surrounding and upstream areas leading to increasing biological oxygen demand and lowering in DO levels (Mnaya et al. 2006). The watershed land use of Umkaliar stream is influenced by a much higher level of anthropogenic activities as compared to the rural watershed of Lwai stream. Also the abundance of chironomidae midge larvae seemed to be exceptionally high during the early to mid-summer season in Umkaliar stream, which may have lowered DO concentration. The relationship between temperature and DO was not significant in Lwai stream as well perhaps because discharge (not measured here) is very high in summer monsoonal months, compensating for the effect of temperature.

Significant differences in turbidity and dissolved oxygen (DO) between the clean Lwai and polluted Umkaliar streams were reflected in distinct macroinvertebrate assemblages observed at each of the streams respectively. Lwai stream with clear water and year-round high DO levels supported pollutionsensitive macroinvertebrates such as stoneflies and mayflies (sensu Rosenberg and Resh 1993, Lamoureaux et al. 2004), while pollution tolerant taxa such as midge larvae and mosquito larvae were common in Umkaliar stream. The high turbidity and low DO concentration in Umkaliar stream was correlated with biotic index scores associated with moderately polluted streams (Sharpe et al. 2006, Feio et al. 2015).

Turbidity was significantly higher during all sampling events in polluted Umkaliar stream compared to Lwai stream. Turbidity is known to limit the ability of oxygen to freely dissolve in water (Hem 1985, Anderson 2005, Bayram et al. 2014, Smith 2015). Lower turbidity in Lwai compared to Umkaliar stream could have influenced DO values. It is also likely that Biological Oxygen Demand (BOD) in Umkaliar stream is higher than that in Lwai due to greater pollution (largely domestic wastewater) and intense anthropogenic use of Umkaliar stream. High levels of BOD 
depress oxygen availability in waters as the processes involving decomposition and chemical reactions of organic matter tend to consume oxygen (Wetzel 2001). In Meghalaya, turbidity is generally caused by sedimentation resulting from deforestation and farming in steep slopes, eroding soil from the entire hilly areas especially in and around the city where hills are cleared for construction, practices such as washing of cars and trucks in the streams, and from dumping of sewage and solid wastes in the rivers which increases the murkiness and lowers the visibility in the streams.

Our data did not exhibit a strong seasonal variation in macroinvertebrate abundances; however patterns in adult emergence and life-history traits are known to influence the abundances of macroinvertebrates in monsoonal streams (Mesa 2012). An expansion of seasonal sampling across many other streams can give a better idea as to whether there are any seasonal differences in macroinvertebrate abundance and diversity in this part of Northeastern India.

\section{Scaling up to the regional level}

Our dataset on spatial variation in stream parameters on both sides of the topographic divide across central Meghalaya (spot sampling) allowed us to assess the range of water quality across sites and determine the effects of turbidity and $\mathrm{DO}$ on macroinvertebrate assemblages, even though these observations are from one or two points in time. Turbidity had a strong negative effect on macroinvertebrate assemblages as exhibited by decline in the biotic index score value with increase in turbidity. In an experimental study conducted in upland and lowland tropical Australian streams (Connolly et al. 2004), pollution sensitive macroinvertebrates show a depressed emergence rate in $25-30 \%$ saturation concentration of DO (4 mg L-1) while the larval abundances showed decline at $8 \%$ saturation concentration (around $2 \mathrm{mg}$ L-1). Studies across taxa show that crustaceans and Chironomidae tolerate as low as $1 \mathrm{mg} \mathrm{L-1}$ DO (Sprague 1968), while pollutions sensitive taxa need more than $5 \mathrm{mg} \mathrm{L}-1$ to avoid lethal consequences (Nebeker 1972). Most of the Meghalayan streams sampled here had relatively high DO values, with the exception of the Umkaliar stream draining urban Shillong where the DO values were as low as $3 \mathrm{mg}$ L-l during the peak rainy season. The ability of fish to survive in low oxygen environments depends upon the extent of exposure, the level and constancy of dissolved oxygen and other environmental conditions, as well as on the species, its health, and life stage (Birtwell1989), which we do not have data on yet, but are working towards making our datasets stronger and comprehensive.

\section{Biomonitoring as a way for capacity building: successes and challenges}

While the studies have amassed interesting datasets in a short time on biotic and abiotic parameters of Meghalayan streams, our project was confronted by multiple challenges. A rapid turnover of students in an undergraduate college allowed us to train several groups of students over three years, but posed a logistical challenge to maintaining long-term studies. Similar to volunteer monitoring organizations that lack adequate technical support due to shortage of quality equipment (funding related) or inability of ground staff to troubleshoot technical problems (dearth of time, funding and experience), that hinder their ability to defend and interpret data on the quality of streams and lakes they monitor (Latimore and Steen 2014), our biomonitoring efforts face similar issues. Data collection efforts were interrupted due to equipment breakdown, lack of time among students and their supervising lecturers, and due to other higher priority activities such as semester and term exams. Yet, amidst these challenges, the colleges in Meghalaya have come forward and recognize that capacity building in the field of freshwater ecology opens up several novel horizons for college students and increases the ability of students and college staff to work for improving water quality in the region. Training in use of open source software and monitoring equipment, introduction to GIS, and data collection and analysis are some tools that are acquired by students working on biomonitoring projects. These tools increase employability of students in other sectors as well. Meghalaya's biomonitoring program now enters it's 3rd year of sampling with the hope that some of the older studies will be revived as newer studies are established.

\section{Future directions}

Apart from the benefits of biomonitoring programs in imparting a hands-on experience that creates a conservation mindset in the next generation, develops skills and adds baseline data on local ecosystems, such programs can be expanded to include examining the relationships between catchment land cover, riparian buffers or gallery forests and stream ecosystems. The role of riparian buffers in providing nutrient inputs and acting as filters that trap sediment from watershed runoff before entering streams is well known globally. It would be important to study that on a 
watershed scale, so as to understand how to restore and manage riparian buffers to maintain water quality and aquatic ecosystems.

The hilly topography and abundant rainfall of Meghalaya leads to swift flowing rivers that are inherently well oxygenated, especially in the rainy season. However, large volume discharges of sewage and other high BOD wastes from urban areas can seriously lower DO levels in water. This DO reduction can be especially harmful in the dry season when flows are low. Apart from pollution via domestic and municipal sewage discharge, sedimentation from runoff from farming, road building, mining and deforestation can also wipe out sensitive invertebrates, with cascading effects upon other aquatic communities, thereby lowering ecosystem integrity and the services a healthy ecosystem provides in terms of clean water and fish resources. Hence, it is imperative to collect more data statewide on aquatic macroinvertebrates together with flow and water quality data from the same streams, and relate that to catchment land use. This data set can then be used to form a biomonitoring metric for Meghalaya, and extend to other hilly northeastern regions, as additional monitoring tools to existing physico-chemical monitoring, but one that gives an integrated picture over catchment and time.

\section{Conclusion}

Ultimately, clean adequate water and aquatic resources (such as fisheries) are necessary for all. Given the increasingly negative human impacts on aquatic ecosystems and their catchments, it is important for society to have a better understanding of the links between ecosystems and water resources, as well as to know how to monitor their local streams, thereby acting as sentinels for noticing adverse changes. The periodic monitoring of aquatic macroinvertebrates in streams indicates the health of the aquatic ecosystem as well as the surrounding catchment, and with that, the status of natural maintenance of water flow and quality. Monitoring, knowing what is the current status is the first step towards management of ecosystems and water resources that necessitates cooperation between all stakeholders involved, from local communities to the government, organizations and educational institutions. With that in mind, giving the current generation the tools and the perspectives is a way to foster a collective conservation mindset. The protection and wise management of natural resources requires our united effort, more than ever in recent history given the ongoing degradation and the looming uncertainty of climate change upon water resources.

\section{References}

Allan, J. D. 1995. Stream Ecology. Structure and function of running waters Chapman and Hall. Boston, Massachusetts, USA. 388 pp.

Allen, D.J, Daniel, B.A and Sanjay M. 2010. The Status and Diversity of Freshwater Biodiversity in the Eastern Himalaya. IUCN Red List of Threatened Species - Regional Assesment. Cambridge, UK and Gland, Switzerland. ISBN: 978-2-8317-1324-3

Anderson, C.W. 2004. Turbidity in National Field Manual for the Collection of Water-Quality Data (TWRI Book 9, chapter A7, section 6.7). U.S. Geological Survey. Accessed August 25, 2016 at http:/ / water.usgs.gov/usgs/owq/6.7-online.pdf. Accessed August 28, 2016.

Basumatary, S.K., S. Dixit, S.K. Bera, S.K. and R. C. Mehrotra. 2013. Modern pollen assemblages of surface samples from Cherrapunjee and its adjoining areas, Meghalaya, northeast India. Quaternary International 298: 68-79

Bayram, A., H. Önsoy, M. Kankal, and M. I. Kömürcü. 2014. Spatial and temporal variation of suspended sediment concentration versus turbidity in the stream Harsit Watershed, NE Turkey. Arabian Journal of Geosciences 7: 4987-4996

Birtwell, I. K. 1989. Comments on the sensitivity of salmonids to reduced levels of dissolved oxygen and to pulp mill pollution in Neroutsos Inlet. Canadian Technical Report of Fisheries and Aquatic Sciences 1956. 27pp

Bonada , N. , N. Prat , V.H. Resh , and B. Statzner. 2006 . Developments in aquatic insect biomonitoring: A comparative analysis of recent approaches. Annual Review of Entomology 51: 495 - 523.

Connolly, N. M., M. R. Crossland and R. G. Pearson. (2004). Effect of low dissolved oxygen on survival, emergence, and drift of tropical stream macroinvertebrates. Journal of the North American Benthological Society 23: 251-270.

Dudgeon, David. 2011. Tropical stream ecology. Academic Press, 2011.

Dudgeon, D., A.H. Arthington, M. O. Gessner, Z. I. Kawabata, D. J. Knowler, C. Lévêque, R. J. Naiman, A. H. Prieur-Richard, D. Soto, M. L Stiassny, and C. A. Sullivan. 2006. Freshwater biodiversity : importance, threats, status and conservation challenges. Biological reviews, 81: 163-182.

Feio, M. J., W. R. Ferreira, D. R. Macedo, A. P. Eller, C. B. M Alves, J. S. França, and M. Callisto, 2015. Defining and testing targets for the recovery of 
tropical streams based on macroinvertebrate communities and abiotic conditions. River Research and Applications, 31:70-84.

Flint, N., Crossland, M.R., Pearson, R.G. 2015. Sublethal effects of fluctuating hypoxia on juvenile tropical Australian freshwater fish. Marine and Freshwater Research 66: 293-304.

Gillain, S. 2005. Diel turbidity fluctuations in streams in Gwinnett County, Georgia. In, K.J. Hatcher (ed.), Proceedings of the 2005 Georgia Water Resources Conference, USGS. Accessed September 2, 2016 at http: / ga.water.usgs.gov/publications / other / gwrc2005/

Giller, P. S. and B. Malmqvist. 1998. The Biology of Streams and Rivers. Oxford University Press, 304 pp.

Goulden, C.E. 2009. Capacity Building for Biomonitoring of Lakes and Streams. Accessed July 14, 2016 athttp://wldb.ilec.or.jp/data/ilec/ WLC13_Papers/S6/s6-3.pdf.

Gupta, Abhik, and R. George Michael. 1992. Diversity, distribution, and seasonal abundance of Ephemeroptera in streams of Meghalaya State, India. Hydrobiologia 228. 131-139.

Gupta, Abhik. 1993. Life histories of two species of Baetis (Ephemeroptera: Baetidae) in a small NorthEast Indian Stream. Archiv für Hydrobiologie 127: 105-114.

Hamid SA, Rawi CSM, Ahmad AH. Life History of Thalerosphyrus (Ephemeroptera: Heptageniidae) in Tropical Rivers with Reference to the Varying Altitude. Tropical Life Sciences Research. 2016: 4362.

Hem, J.D. 1985. Study and Interpretation of the Chemical Characteristics of Natural Water, 3rd edition. USGS. Water-Supply Paper 2254.

Karr, J.R. 1999. Defning and measuring river health. Freshwater Biology 41: 221 - 234.

Kenney, M.A., A.E. Sutton-Grier, R.A. Smith, and S.E. Gresens. 2009. Benthic macroinvertebrates as indicators of water quality: The intersection of science and policy. Terrestrial Arthropod Reviews 2 : 99128.

Lamouroux, N., S. Doledec, and S. Gayraud. 2004. Biological traits of stream macroinvertebrate communities: Effects of microhabitat, reach, and basin filter . Journal of the North American Benthological Society 2: 449 - 466.

Lamare R. E., and O. P. Singh. 2016. Seasonal Variation in Water Quality of Lukha River, Meghalaya, India. Current World Environment 11:101-113.

Latimore, J. A., and P. J. Steen Paul. 2014. Integrating
Freshwater Science and Local Management through Volunteer Monitoring Partnerships: The Michigan Clean Water Corps. Freshwater Science 33: 686-92.

Massar, B., Saha, S. 2016. Fish diversity and catchment land-use of river Rymben in East Khasi Hills, Meghalaya. Pages 44-48 in Proceedings of the international conference on water resource management in the Eastern Himalayan region. Jyrwa, E., M. Pyngrope, S. Saha, B. Massar, (eds.). St. Anthony's College Publication, Mawsawa Press, Shillong, Meghalaya.

Martin, P., M. A. Haniffa, and M. Arunachalam. 2000. Abundance and diversity of macroinvertebrates and fish in the Tamiraparani river, South India. Hydrobiologia 430: 59-63.

Merritt, R.W., K.W. Cummins, and M.B. Berg. 2008. An Introduction to the Aquatic Insects of North America. 4th edition. Kendall Hunt Publishing. Dubuque, Iowa, U.S.A. 1158 pp.

Mesa, LM. 2012. Interannual and seasonal variability of macroinvertebrates in monsoonal climate streams. Brazilian Archives of Biology and Technology, 55: 403-410

Michaud, J.P. 1991. A Citizens' Guide to Understanding and Monitoring Lakes and Streams. Published by Washington State Department of Ecology Press. 73pp.

Miller, S. W., D. Wooster, D. and J. Li. 2007. Resistance and resilience of macroinvertebrates to irrigation water withdrawals. Freshwater Biology 52: 24942510.

Mnaya, B., Mwangomo, E., Wolanski, E. 2006. The influence of wetlands, decaying organic matter, and stirring by wildlife on the dissolved oxygen concentration in eutrophicated water holes in the Seronera River, Serengeti National Park, Tanzania. Wetlands Ecology and Management 14:421-425.

Mosley, L. M., B. Zammit, E. Leyden, T.M. Heneker, M.R. Hipsey, D. Skinner, and K. T. Aldridge. 2012. The impact of extreme low flows on the water quality of the Lower Murray River and Lakes (South Australia). Water Resources Management, 26: 3923-3946.

Myre, E. and R. Shaw. 2006. The Turbidity Tube: Simple and Accurate Measurement of Turbidity in the Field, CE 5993 Field Engineering in the Developing World and FW 5770 Community Planning and Analysis, Michigan Technological University, Houghton, pp. 3-4.

Nebeker, A. V. 1972. Effect of low oxygen concentration on survival and emergence of aquatic insects. 
Transactions of the American Fisheries Society 4:675-679.

Rabha, B., S. Dhiman, K. Yadav, S. Hazarika, R.K. Bhola, and V. Veer. 2013. Influence of water physicochemical characteristics on Simuliidae (Diptera) prevalence in some streams of Meghalaya, India. Journal of Vector Borne Diseases 50: 18-23

Rosenberg, D. M., and V.H. Resh. 1993. Freshwater Biomonitoring and Benthic Macroinvertebrates. Chapman and Hall, New York, USA. 488 pp.

Saha, S. 2016. Capacity building in ecohydrology in Indian Northeast. Pages 77-82 in Proceedings of the international conference on water resource management in the Eastern Himalayan region. Jyrwa, E., M. Pyngrope, S. Saha, B. Massar, (eds.). St. Anthony's College Publication, Mawsawa Press, Shillong, Meghalaya.

Shah, R. D. T., and D. N. Shah. 2013. Evaluation of benthic macroinvertebrate assemblage for disturbance zonation in urban rivers using multivariate analysis: Implications for river management. Journal of Earth System Science, 122: 1125-1139.

Sharpe, W.E., W.G. Kimmel, and A. R. Buda, 2002. Biotic Index Guide. Pennsylvania State University, Smith, D. 2015. Spatial and Temporal Variation in
Water Quality along an Urban Stretch of the Chattahoochee River and Proctor Creek in Atlanta, GA. Thesis, Georgia State University, 408 pp Accessed August 23, 2016 at http:// scholarworks.gsu.edu/iph_theses/

Sprague, J. B. 1963. Resistance of four freshwater crustaceans to lethal high temperature and low oxygen. Journal of the Fisheries Research Board of Canada 20:387-415.

Subramanian, K.A. and K. G. Sivaramakrishnan. 2007. Aquatic Insects of India-A Field Guide. Ashoka Trust for Ecology and Environment, Bangalore, India. 62pp.

van Vliet, M. T., W.H. Franssen, J.R. Yearsley, F. Ludwig, I. Haddeland, I., Lettenmaier, D. P. and P. Kabat. 2013. Global river discharge and water temperature under climate change. Global Environmental Change 23: 450-464.

Williams, D. D., 1996. Environmental constraints in temporary fresh waters and their consequences for the insect fauna. Journal of the North American Benthological Society 15:634-650.

Wetzel, R. G. 2001. Limnology : Lake and River Ecosystems, 3rd ed. San Diego, CA: Academic Press. 